Article

\title{
Anti-Inflammatory Effect of Lupinalbin A Isolated from Apios americana on Lipopolysaccharide-Treated RAW264.7 Cells
}

\author{
Hyo-Young Kim ${ }^{1,2}$, Jang Hoon Kim ${ }^{1}$, YangKang So ${ }^{3}$, Si-Yong Kang ${ }^{1}$, Hye Gwang Jeong ${ }^{2}$ and \\ Chang Hyun Jin ${ }^{1, *}$ \\ 1 Advanced Radiation Technology Institute, Korea Atomic Energy Research Institute, Jeongeup, Jeonbuk \\ 56212, Korea; khy5012@kaeri.re.kr (H.-Y.K.); kjh53@kaeri.re.kr (J.H.K.); sykang@kaeri.re.kr (S.-Y.K.) \\ 2 College of Pharmacy, Chungnam National University, Daejeon 34134, Korea; hgjeong@cnu.ac.kr \\ 3 Institute of Natural Cosmetic Industry for Namwon, Namwon, Jeonbuk 55801, Korea; yangkang@ncn.re.kr \\ * Correspondence: chjin@kaeri.re.kr; Tel.: +82-63-570-3162; Fax: +82-63-570-3813
}

Received: 25 January 2018; Accepted: 1 March 2018; Published: 6 March 2018

\begin{abstract}
Apios americana, a leguminous plant, is used as food in some countries. Although the biological activities of Apios extract have been reported, there have been no reports about the anti-inflammatory mechanism of lupinalbin A on the RAW264.7 cells. In this study, we investigated the anti-inflammatory effect of $A$. americana lupinalbin A on lipopolysaccharide (LPS)-treated RAW264.7 cells. Lupinalbin A significantly inhibited nitric oxide production and inducible nitric oxide synthase expression in LPS-treated RAW264.7 cells. The expression of cytokines, including interleukin-6, tumor necrosis factor- $\alpha$, and chemokine of monocyte chemoattractant protein, was reduced under lupinalbin A exposure in LPS-treated RAW264.7 cells. In addition, lupinalbin A significantly decreased LPS-induced interferon (IFN)- $\beta$ production and STAT1 protein levels in RAW264.7 cells. Taken together, these results suggest that A. americana lupinalbin A exerts anti-inflammatory effects via the inhibition of pro-inflammatory cytokines and blocking of IFN- $\beta /$ STAT1 pathway activation.
\end{abstract}

Keywords: anti-inflammatory effects; Apios americana; lipopolysaccharide; lupinalbin A

\section{Introduction}

Inflammation is an immune response that occurs following noxious stimulation, such as infection and tissue injury [1]. However, excessive inflammation contributes to the pathogenesis of chronic diseases, such as arthritis, asthma, and atherosclerosis [2-4]. Macrophages and phagocytes play important roles in host immune defense. During inflammation, activation of macrophages leads to the production of many pro-inflammatory cytokines (interleukin(IL)-6, IL-1 $\beta$, and tumor necrosis factor(TNF)- $\alpha$ ), prostaglandin $E_{2}$, and nitric oxide (NO). NO is a short-lived free radical and is synthesized by NO synthase (NOS). Three different isoforms of NOS exist and are referred to as neuronal NOS (nNOS), inducible NOS (iNOS), and endothelial NOS (eNOS) [5]. Lipopolysaccharide (LPS) is constituents of the cell walls of gram-negative bacteria and is act as activator of the immune system. LPS-stimulated macrophages induce the expression of iNOS, which stimulates NO production [6].

LPS is recognized by toll-like receptor 4 , which proceeds via two different signal pathways: the MyD88- and TRIF-dependent pathways. The MyD88-dependent pathway mediates the activation of mitogen-activated protein kinases, such as p38, extracellular signal-regulated kinase $1 / 2$, and c-Jun NH2-terminal kinase. The stimulation of the TRIF-dependent pathway leads to the activation of interferon regulatory factor-3 (IRF3) and induction of interferon (IFN)- $\beta$ expression [7], the IFN- $\beta$ 
phosphorylates of signal transducer and activator of transcription 1 (STAT1) via the stimulation of the IFN- $\beta$ receptor. Activation of the MyD88- and TRIF-dependent pathways leads to the expression of cytokines, including TNF- $\alpha$, IL-6, IL-1 $\beta$, and IFN- $\beta$, through transcriptional factors, such as NF- $\mathrm{KB}$, AP-1, and IRF3 [8]. In particular, nuclear translocation of transcription factors, such as $\mathrm{NF}-\mathrm{KB}, \mathrm{AP}-1$, and IRF3 is known to modulate inflammatory response and up-regulation of the iNOS expression [9-11]. Therefore, the blockade of these pathways may represent important strategies in the treatment of inflammatory diseases.

Apios americana Medik, a perennial plant belonging to the family of legumes, is native to North America. The roots of $A$. americana grow to a depth of $>1 \mathrm{~m}$, with tubers attached to the fibrous roots 5-10 cm apart [12]. A recent study has reported the nutritional value of Apios tubers and their fatty acid and amino acid compositions [13,14]. Another study has demonstrated that Apios exhibits anti-hypertensive properties [15]. Other studies have reported immunostimulatory activities of Apios tuber extract [16]; however, studies on the anti-inflammatory effects of lupinalbin A isolated from $A$. americana and the underlying mechanism have not yet been reported.

This study aimed to investigate the anti-inflammatory effects of lupinalbin A isolated from A. americana on NO production and the underlying molecular mechanism in LPS-treated RAW264.7 cells.

\section{Results}

\subsection{Effect of Lupinalbin A on Cell Cytotoxicity}

Based on EZ-Cytox cell viability assays, we measured the cytotoxicity of lupinalbin A in RAW264.7 cells. As shown in Figure 1B, lupinalbin A showed no effect at concentrations below $100 \mu \mathrm{M}$; however, cell viability was reduced at concentrations of 150 and $200 \mu \mathrm{M}$. Therefore, in subsequent studies we used lupinalbin A concentrations ranging from 5 to $100 \mu \mathrm{M}$.

\subsection{Effect of Lupinalbin A on LPS-Induced NO Production in RAW264.7 Cells}

To investigate the anti-inflammatory effects of lupinalbin A, NO production was determined in LPS-treated RAW264.7 cells (Figure 2A). RAW264.7 cells were pre-treated with various concentrations of lupinalbin A (5-100 $\mu \mathrm{M})$ for $2 \mathrm{~h}$ and then incubated with LPS $(1 \mu \mathrm{g} / \mathrm{mL})$ for $18 \mathrm{~h}$. NO was produced following LPS treatment, which was inhibited by $18.7 \%, 36.7 \%$, and $64.2 \%$ following the addition of 25 , 50 , and $100 \mu \mathrm{M}$ lupinalbin A, respectively. To further elucidate whether the inhibition of NO production by lupinalbin A was due to the suppression of iNOS expression, the protein and mRNA levels of iNOS were measured. As shown in Figure 2B, pre-treatment with lupinalbin A downregulated the expression of iNOS protein in LPS-treated RAW264.7 cells in a concentration-dependent manner. Moreover, RT-PCR analysis showed that the mRNA levels of iNOS were significantly reduced by lupinalbin $\mathrm{A}$ in a dose-dependent manner (Figure 2C). Our results indicated that lupinalbin A attenuated NO production by suppressing iNOS expression in LPS-treated RAW264.7 cells.

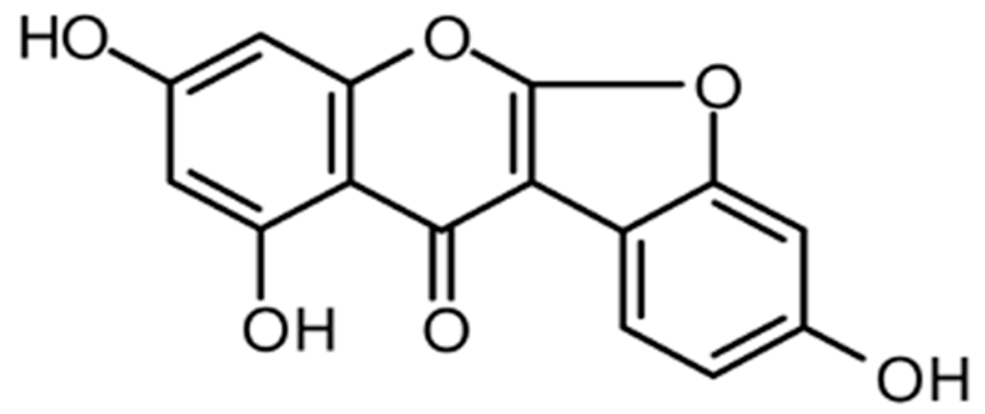

(A)

Figure 1. Cont. 


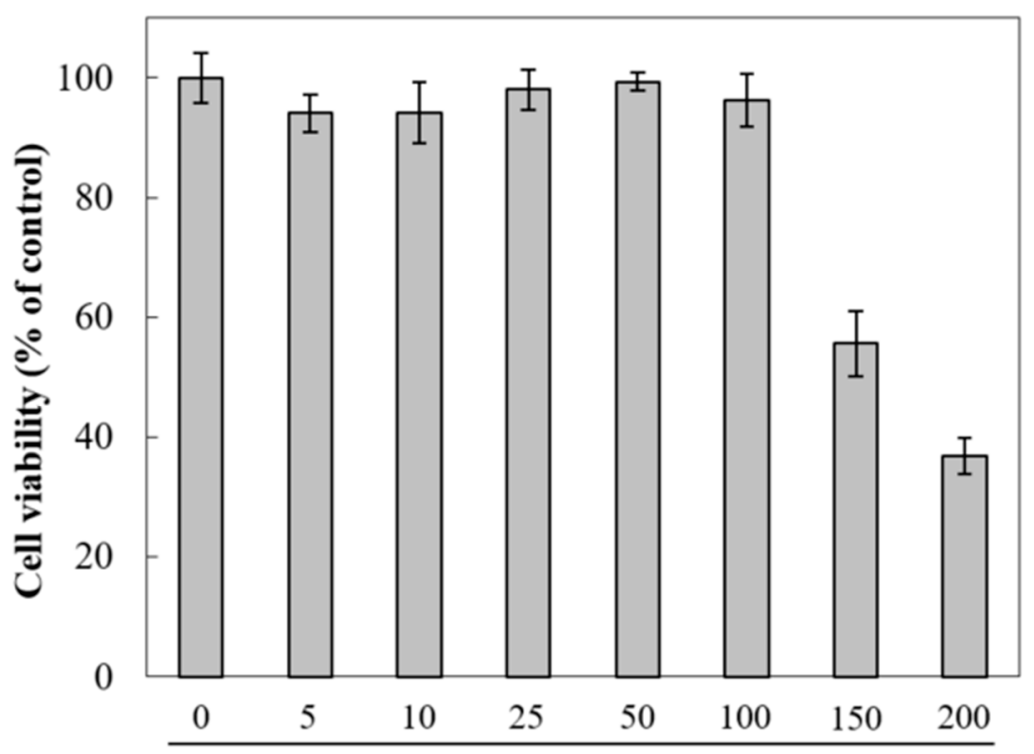

Lupinalbin A $(\mu \mathrm{M})$

(B)

Figure 1. Chemical structure of lupinalbin A and effect of lupinalbin A on cell viability in RAW264.7 cells. (A) The chemical structure of lupinalbin A; (B) Cell viability was measured by EZ-Cytox cell viability assay. Cells were treated with various concentrations of lupinalbin A (5-200 $\mu \mathrm{M})$ for $24 \mathrm{~h}$. The data are presented as mean $\pm \operatorname{SDs}(n=6)$.

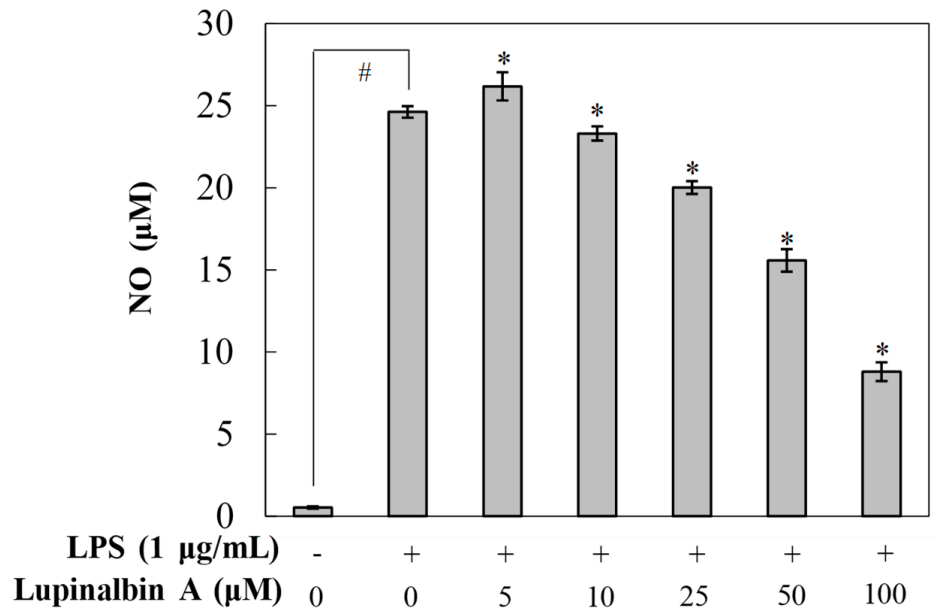

(A)

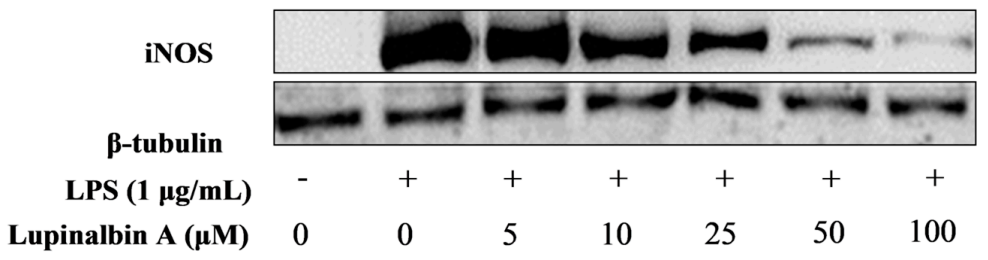

(B)

Figure 2. Cont. 


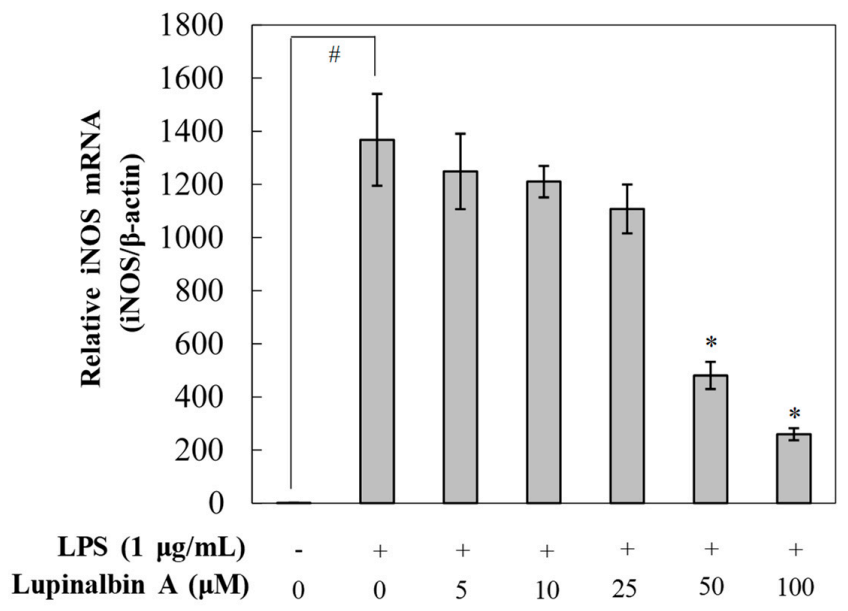

(C)

Figure 2. Effect of lupinalbin A on NO production and iNOS protein and iNOS mRNA expression in LPS-treated RAW264.7 cells. (A) Cells were treated with various concentrations of lupinalbin A $(5-100 \mu \mathrm{M})$ for $2 \mathrm{~h}$ and then incubated with LPS $(1 \mu \mathrm{g} / \mathrm{mL})$ for $18 \mathrm{~h}$. The data are presented as mean \pm SDs $(n=6)$. ${ }^{*} p<0.05$ vs. control group, ${ }^{*} p<0.05$ vs. LPS-treated group; (B) iNOS protein levels were measured by western blot; $(\mathbf{C})$ Cells were treated with various concentrations of lupinalbin A $(5-100 \mu \mathrm{M})$ for $2 \mathrm{~h}$ and then stimulated with LPS $(1 \mu \mathrm{g} / \mathrm{mL})$ for $18 \mathrm{~h}$. iNOS mRNA expression levels were measured by qRT-PCR. The data are presented as mean \pm SDs $(n=3) .{ }^{*} p<0.05$ vs. control group, * $p<0.05$ vs. LPS-treated group.

\subsection{Effect of Lupinalbin A on Production of LPS-Induced Pro-Inflammatory Cytokines in RAW264.7 Cells}

Next, we evaluated the effects of lupinalbin A on the production of pro-inflammatory cytokines in LPS-treated RAW264.7 cells using ELISA (Figure 3). The cells were pre-treated with various concentrations of lupinalbin A $(5-100 \mu \mathrm{M})$ for $2 \mathrm{~h}$ and then stimulated with LPS $(1 \mu \mathrm{g} / \mathrm{mL})$ for $4 \mathrm{~h}$. LPS treatment significantly increased the production of IL- 6 , TNF- $\alpha$, and MCP- 1 by 235.8 -fold, 17.5-fold, and 28.9-fold, respectively, compared with control cells. Pre-treatment with $100 \mu \mathrm{M}$ lupinalbin A markedly reduced IL-6 levels by $90.2 \%$, whereas treatment with $100 \mu \mathrm{M}$ lupinalbin A significantly decreased TNF- $\alpha$ and MCP-1 levels by $79.8 \%$ and $49.3 \%$, respectively. These results suggested that lupinalbin A efficiently decreased the production of pro-inflammatory cytokines in LPS-treated RAW264.7 cells.

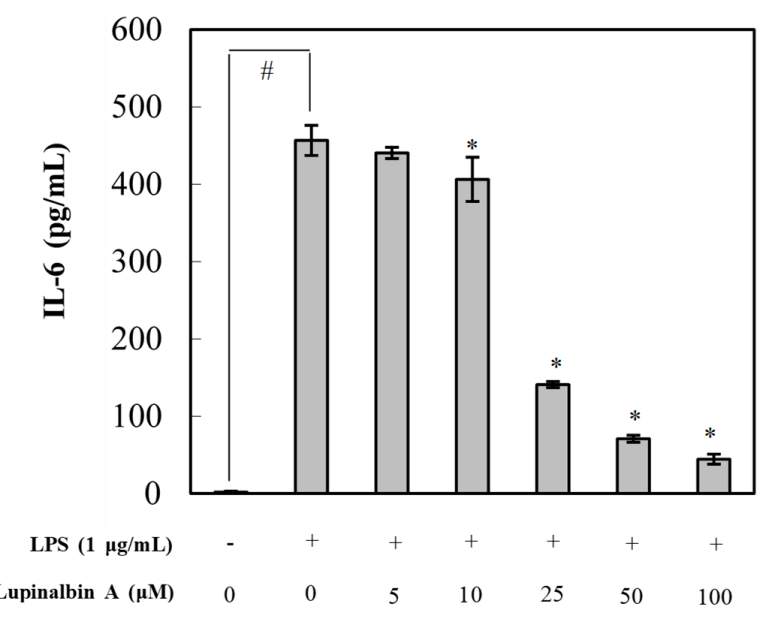

(A)

Figure 3. Cont. 


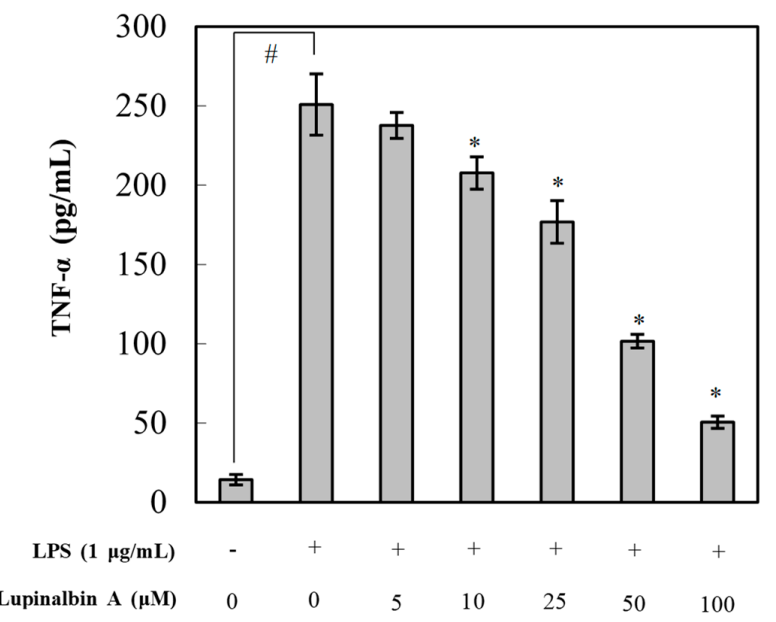

(B)

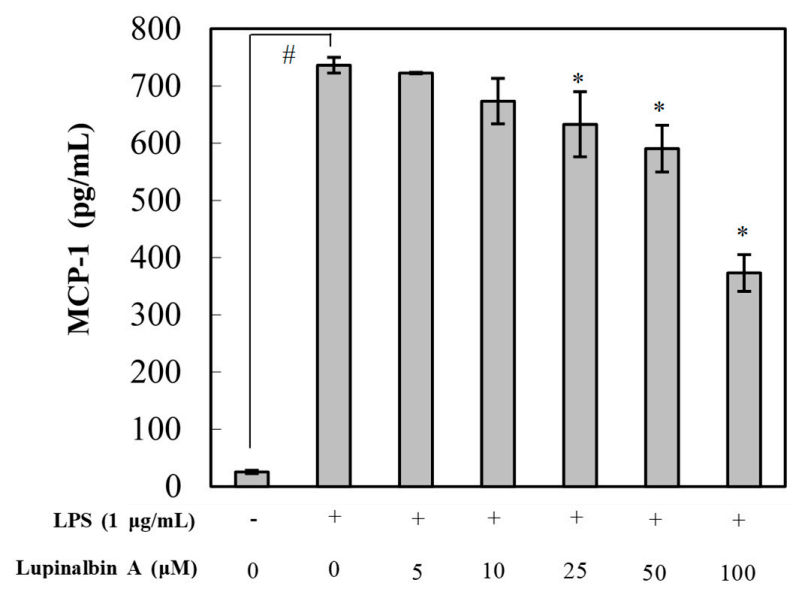

(C)

Figure 3. Effect of lupinalbin A on (A) IL-6; (B) TNF- $\alpha$; and (C) MCP-1 production in LPS-treated RAW264.7 cells. The cells were treated with various concentrations of lupinalbin A $(5-100 \mu \mathrm{M})$ for $2 \mathrm{~h}$ and then stimulated with LPS $(1 \mu \mathrm{g} / \mathrm{mL})$ for $18 \mathrm{~h}$. IL-6, TNF- $\alpha$, and MCP- 1 production was determined by ELISA. The data are presented as mean \pm SDs $(n=3) .{ }^{\#} p<0.05$ vs. control group, ${ }^{*} p<0.05$ vs. LPS-treated group.

\subsection{Effect of Lupinalbin A on LPS-Induced Expression of IL-6, TNF- $\alpha$, and MCP-1 $m R N A$}

To investigate the inhibitory effect of lupinalbin A on the expression of IL- 6 , TNF- $\alpha$, and MCP-1 mRNA, RT-PCR was performed. As shown in Figure 4, stimulation with LPS significantly promoted the expression of IL- 6 , and MCP-1 except TNF- $\alpha$ mRNA compared with control; however, lupinalbin A treatment repressed the expression of IL-6, TNF- $\alpha$, and MCP-1 mRNA in a dose-dependent manner (IL-6, TNF- $\alpha$, MCP-1; 88.5\%, 58.1\%, 63.8\% inhibition at $100 \mu \mathrm{M}$, respectively). 


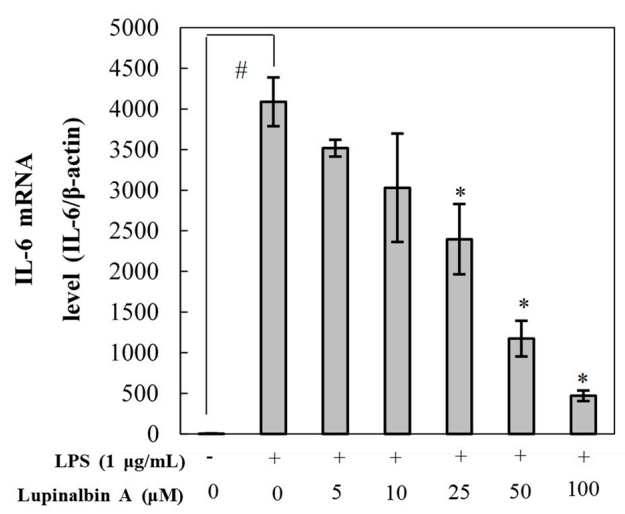

(A)

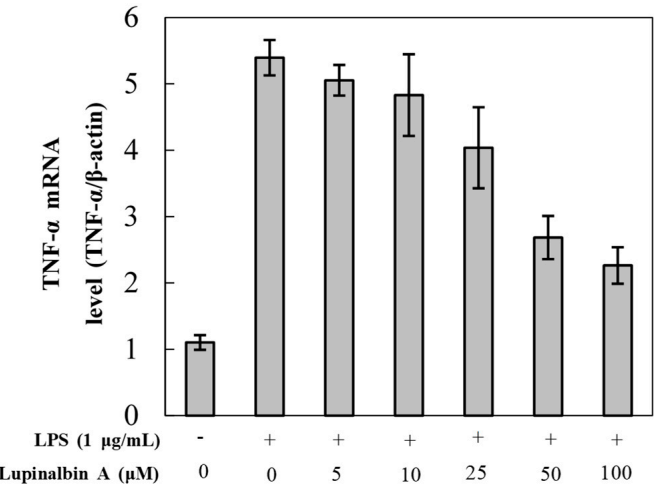

(B)

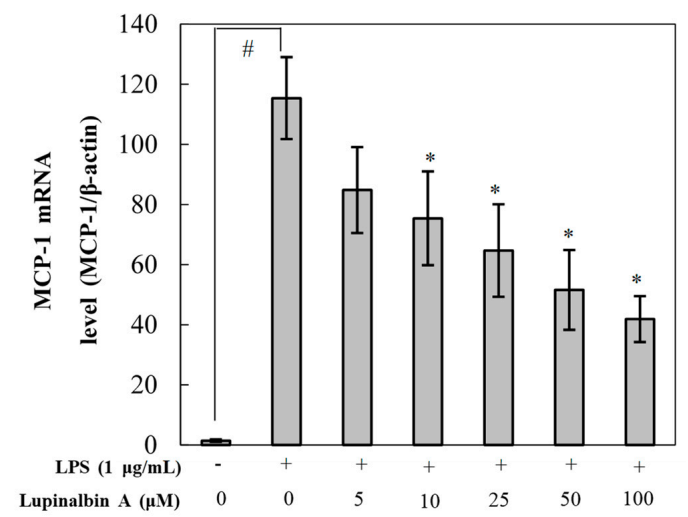

(C)

Figure 4. Effect of lupinalbin A on (A) IL-6; (B) TNF- $\alpha$; and (C) MCP-1 mRNA expression in LPS-treated RAW264.7 cells. Cells were treated with various concentrations of lupinalbin A (5-100 $\mu \mathrm{M})$ for $2 \mathrm{~h}$ and then stimulated with LPS $(1 \mu \mathrm{g} / \mathrm{mL})$ for $18 \mathrm{~h}$. IL-6, TNF- $\alpha$, and MCP-1 mRNA expression levels were determined by qRT-PCR. The data are presented as mean \pm SDs $(n=3) .{ }^{\#} p<0.05$ vs. control group, * $p<0.05$ vs. LPS-treated group.

\subsection{Effect of Lupinalbin A on LPS-Induced IFN- $\beta$ Production and STAT1 Activation in RAW264.7 Cells}

To understand the effect of lupinalbin A on the downregulation of iNOS expression, the effects of lupinalbin A on LPS-induced IFN- $\beta$ production and STAT1 activation were examined. As shown Figure $5 \mathrm{~A}$, pre-treatment with lupinalbin A significantly suppressed IFN- $\beta$ production in a dose-dependent manner, with an $\mathrm{IC}_{50}$ value of $47.53 \mu \mathrm{M}$. Furthermore, the effect of lupinalbin A on STAT1 protein was also investigated; the results showed that lupinalbin A significantly inhibited STAT1 protein expression in a concentration-dependent manner (Figure 5B). 


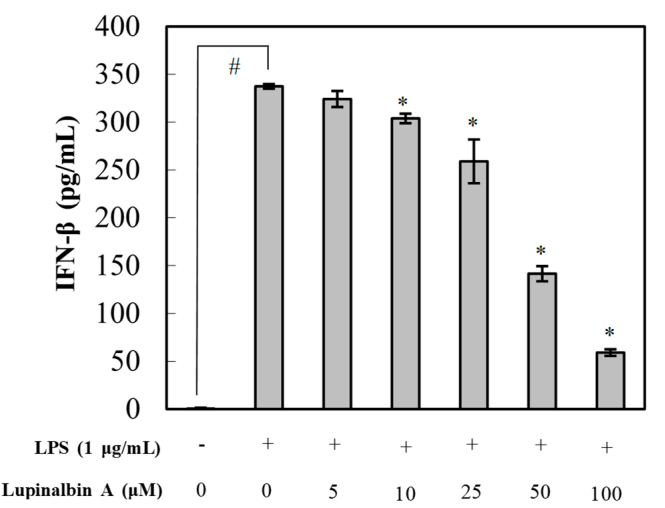

(A)

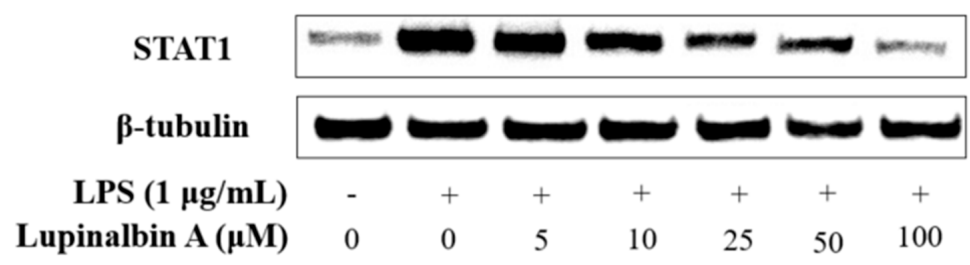

(B)

Figure 5. Effect of lupinalbin A on IFN- $\beta$ production and STAT1 protein in LPS-treated RAW264.7 cells. (A) Cells were treated with various concentrations of lupinalbin A (5-100 $\mu \mathrm{M})$ for $2 \mathrm{~h}$ and then stimulated with LPS $(1 \mu \mathrm{g} / \mathrm{mL})$ for $18 \mathrm{~h}$. IFN- $\beta$ production was determined by ELISA. The data are presented as mean \pm SDs $(n=3)$. ${ }^{\#} p<0.05$ vs. control group, ${ }^{*} p<0.05$ vs. LPS-treated group; (B) STAT1 protein levels were measured by western blot analysis.

\section{Discussion}

A. americana Medik has traditionally been believed to confer health benefits in several diseases [17,18]. Cui et al. [16] have reported that Apios tuber extract increases NO production in RAW264.7 cells and promotes mRNA and protein expression of iNOS and COX-2. Pro-inflammatory cytokines, such as TNF- $\alpha$, IL-1 $\beta$, and IL-6, were also increased. Moreover, immunoregulation by isoflavones, particularly genistein, daidzein, and glycitein, have been reported [19]. In addition, several studies have reported that the lectin shows immunostimulatory activity [20-22]. In addition to its immunostimulatory activity, Apios has been reported to exhibit anti-hypertension, sEH inhibitory, anti-cancer, and anti-inflammatory activities [23-25]. Sohn et al. [24] have reported that Apios exerts a protective effect against LPS- and H1N1-induced acute lung injury by reducing inflammation in the lung. These anti-inflammatory effects were attributed to genistein-7-O-gentiobioside and glycoprotein. In this study, we isolated lupinalbin A from Apios tuber, determined the structure (Supplementary Materials Figures S1 and S2) and confirmed its anti-inflammatory activity in LPS-treated RAW264.7 cells.

Several studies have reported the isolation of lupinalbin A, a type of flavonoid, from Apios, Flemingia, white lupin, mung bean, and Eriosema laurentii de Wild, and it has been found to show osteoblast differentiation-promoting, anti-proliferative, antioxidant, estrogenic, and aryl hydrocarbon receptor agonistic activities [26-31]. Particularly, estrogen has been reported to have anti-inflammatory effects [32], and estrogen receptor (ER) activity is an important step in the inflammatory responses [33]. Nevertheless, the anti-inflammatory effects of lupinalbin A and the underlying mechanisms have not yet been evaluated. Therefore, we investigated the mechanisms and anti-inflammatory effects of lupinalbin A isolated from Apios in LPS-treated RAW264.7 cells.

Excessive NO production, catalyzed by iNOS, occurs in inflammation and various diseases, in which NO acts as a cytotoxic agent in the pathological processes [34,35]. Therefore, the inhibition of NO production is essential for preventing inflammatory diseases. In the present study, we showed that 
pre-treatment with lupinalbin A inhibited NO production and iNOS mRNA and protein expressions in LPS-treated RAW264.7 cells.

Among other inflammatory stimulators, LPS has been reported to induce macrophage activation, leading to the release of pro-inflammatory cytokines (TNF- $\alpha$ and IL-6) and chemokines (MCP-1) in inflammatory responses [36,37]. Cytokine causes fever, shock, and a variety of inflammatory diseases. Hence, it is important to suppress pro-inflammatory cytokine overproduction. Our results indicated that pre-treatment with lupinalbin A suppressed mRNA expression and TNF- $\alpha$, IL-6, and MCP-1 production in LPS-treated RAW264.7 cells in a dose-dependent manner.

To investigate the anti-inflammatory mechanism of lupinalbin A, we identified two principal pathways: the MyD88- and TRIF-dependent pathways, in LPS-stimulated RAW264.7 cells. A previous study reported that RAW264.7 cells secrete IFN- $\alpha / \beta$ by LPS induction and these IFNs induce MCP-1 and iNOS expression through an autocrine/paracrine mechanism [38]. In the TRIF-dependent pathway, lupinalbin A reduced the expression of MCP- 1 by suppressing the production of IFN- $\beta$. In the MyD88-dependent pathway, lupinalbin A decreased the production of IL-6, iNOS, and NO. Further studies are needed to determine whether lupinalbin A affects the upstream level of MyD88- and TRIF-dependent pathways.

IFN- $\beta$ plays a critical role in host defense against various viral infections [11]. LPS-induced IFN- $\beta$ correlates with pathophysiology in inflammation. Here, we found that lupinalbin A significantly decreased LPS-induced IFN- $\beta$ production and STAT1 protein in RAW264.7 cells. Thus, these results suggest that lupinalbin A reduces NO production and iNOS expression through STAT1 suppression by blocking IFN- $\beta$ production in LPS-treated RAW264.7 cells.

In summary, our results demonstrated that lupinalbin A inhibited NO and pro-inflammatory cytokine production, as well as and iNOS mRNA and protein expression in LPS-treated RAW264.7 cells in a concentration-dependent manner. Furthermore, lupinalbin A decreased STAT1 expression and IFN- $\beta$ production in LPS-treated RAW264.7 cells. These results indicated that because of its anti-inflammatory effects, lupinalbin A isolated from Apios represents a potential anti-inflammatory agent for the natural treatment of inflammatory diseases. In the future, we plan to study whether lupinalbin A exhibits anti-inflammatory effects in inflammatory disease models.

\section{Material and Methods}

\subsection{General Experimental Procedures}

Optical rotation was measured using a JASCO P-1020 polarimeter. CD spectra were recorded on a JASCO J-600 spectrometer (JASCO Inc., Easton, MD, USA). Column chromatography was performed using silica gel (Kieselgel 60, 70-230, and 230-400 mesh, Merck, Darmstadt, Germany), Sephadex LH-20 (GE Healthcare, Uppsala, Sweden), and YMC RP-18 resins. Thin layer chromatography was performed using pre-coated silica-gel $60 \mathrm{~F}_{254}$ and RP- $18 \mathrm{~F}_{254 \mathrm{~s}}$ plates (both $0.25 \mathrm{~mm}$, Merck, Darmstadt, Germany). Spots were visualized by spraying with $10 \%$ aqueous $\mathrm{H}_{2} \mathrm{SO}_{4}$ solution, followed by heating. NMR spectra were recorded using a JEOL ECA 500 spectrometer $\left({ }^{1} \mathrm{H}, 500 \mathrm{MHz} ;{ }^{13} \mathrm{C}, 125 \mathrm{MHz}\right)$ (JEOL Ltd., Tokyo, Japan). Mass spectra were measured using an Agilent LC-MS 6100 system (Agilent, Santa Clara, CA, USA).

\subsection{Chemicals}

LPS, sodium nitrite, phenylmethylsulfonyl fluoride, NP40 cell lysis buffer, dimethyl sulfoxide, protease inhibitor cocktail, and Griess reagent were purchased from Sigma-Aldrich (St. Louis, MO, USA). Dulbecco's Modified Eagle's Medium (DMEM) and fetal bovine serum (FBS) were purchased from Hyclone (Logan, UT, USA). The EZ-Cytox cell viability assay kit was purchased from DAEIL lab (Seoul, Korea). The RNeasy kit was purchased from QIAGEN (Valencia, CA, USA). The PrimeScript II 1st Strand cDNA Synthesis Kit and SYBR premix were purchased from Takara Bio Inc. (Tokyo, Japan). Anti-iNOS and -STAT1 antibodies were purchased from Cell Signaling Technology 
(Danvers, MA, USA), anti- $\beta$-tubulin antibody was purchased from Santa Cruz Biotechnology (Santa Cruz, CA, USA), and goat anti-rabbit IgG horseradish peroxidase (HRP)-conjugated secondary antibody was purchased from Invitrogen (Carlsbad, CA, USA). Enzyme-linked immunosorbent assay (ELISA) kits for IL-6, TNF- $\alpha$, and monocyte chemoattractant protein (MCP-1) were purchased from R\&D Systems (Minneapolis, MN, USA), and the ELISA kit for IFN- $\beta$ was purchased from Pestka Biomedical Laboratories (Piscataway, NJ, USA).

\subsection{Plant Materials}

Tubers of A. americana (voucher specimen RBRC 001) were cultivated and collected locally from Jeoungeup, Jeollabukdo, Korea. This species was identified by Dr. S. Y. Kang of the Radiation Breeding Research Center, Korea Atomic Energy Research Institute.

\subsection{Extraction, Fractionation, and Isolation of A. americana}

Dried A. americana tubers $(4 \mathrm{~kg})$ were extracted using 95\% methanol $(4 \mathrm{~L} \times 3$ times) for a week at room temperature. The crude extract ( $337 \mathrm{~g})$ was condensed under reduced pressure and dissolved in $3 \mathrm{~L}$ of $\mathrm{H}_{2} \mathrm{O}$. The suspended extract was partitioned using $n$-hexane, ethyl acetate, butanol, and $\mathrm{H}_{2} \mathrm{O}$. The ethyl acetate fraction $(9 \mathrm{~g})$ was separated by silica gel column chromatography using a chloroform/methanol gradient $(30: 1 \rightarrow 3: 1)$ to yield 12 fractions (E1-E12). The E5 fraction was subjected to C-18 column chromatography with a water/methanol gradient elution $(2: 1 \rightarrow 1: 5)$ to obtain four fractions (E51-E54). The E53 fraction was subjected to Sephadex LH-20 column chromatography using $95 \%$ methanol to yield compound $\mathbf{1}(12 \mathrm{mg})$. The structure is shown in Figure 1A.

\subsection{Cell Culture}

RAW264.7 macrophages were purchased from the American Type Culture Collection (Manassas, VA, USA). Cells were cultured in DMEM supplemented with 10\% FBS, 100 units $/ \mathrm{mL}$ of penicillin, and $100 \mu \mathrm{g} / \mathrm{mL}$ of streptomycin (Invitrogen, Carlsbad, CA, USA) at $37{ }^{\circ} \mathrm{C}$ in $5 \% \mathrm{CO}_{2}$ atmosphere.

\subsection{Cytotoxicity Assay}

Cytotoxicity was measured using an EZ-Cytox cell viability assay kit. Briefly, cells were cultured in 96-well plates at a density of $2 \times 10^{5}$ cells $/ \mathrm{mL}$ for $24 \mathrm{~h}$. The cells were treated with various concentrations of lupinalbin A $(5-200 \mu \mathrm{M})$. After an additional $24 \mathrm{~h}$ of incubation at $37^{\circ} \mathrm{C}, 10 \mu \mathrm{L}$ of the kit solution was added to each well and incubated for $4 \mathrm{~h}$ at $37{ }^{\circ} \mathrm{C}$ in $5 \% \mathrm{CO}_{2}$ atmosphere. For determining formazan production, the resulting color was assessed by measuring absorbance at $480 \mathrm{~mm}$ using an ELISA reader (Benchmark Plus, Bio-Rad, Hercules, CA, USA). The reference wavelength was $650 \mathrm{~nm}$.

\subsection{Measurement of NO Production}

Cells were cultured in 96-well plates at a density of $2 \times 10^{5}$ cells $/ \mathrm{mL}$ for $24 \mathrm{~h}$. The cells were pre-treated with various concentrations of lupinalbin $\mathrm{A}(5-100 \mu \mathrm{M})$ for $2 \mathrm{~h}$ and then incubated with LPS $(1 \mu \mathrm{g} / \mathrm{mL})$ for $18 \mathrm{~h}$ at $37^{\circ} \mathrm{C}$ in $5 \% \mathrm{CO}_{2}$ atmosphere. The culture supernatant $(100 \mu \mathrm{L})$ was mixed with Griess reagent $(100 \mu \mathrm{L})$ and incubated at room temperature for $15 \mathrm{~min}$. Absorbance at $540 \mathrm{~nm}$ was measured using an ELISA reader. The quantity of nitrite was determined using a sodium nitrite standard curve. The results are presented as mean \pm standard deviations (SDs) of six replicates for one representative experiment.

\subsection{Western Blot}

Cells were cultured in 100-mm culture dishes at a density of $2 \times 10^{5}$ cells $/ \mathrm{mL}$ for $24 \mathrm{~h}$. The cells were pre-treated with various concentrations of lupinalbin $A(5-100 \mu \mathrm{M})$, incubated for $2 \mathrm{~h}$, and then 
incubated with LPS $(1 \mu \mathrm{g} / \mathrm{mL})$ for $18 \mathrm{~h}$ at $37{ }^{\circ} \mathrm{C}$ in $5 \% \mathrm{CO}_{2}$ atmosphere. The cells were harvested and lysed using NP40 cell lysis buffer (with $1 \mathrm{mM}$ phenylmethylsulfonyl fluoride and $1 \times$ protease inhibitor cocktail) for $30 \mathrm{~min}$ on ice. The protein concentration of the cell lysate was measured using the Bio-Rad Protein Assay (Bio-Rad, Hercules, CA, USA). Aliquots of $30-\mu$ g protein were loaded and electrophoresed on $10 \%$ SDS-PAGE and then transferred onto nitrocellulose membranes (Hybond ECL Nitrocellulose; GE Healthcare, Chandler, AZ, USA). The membranes were washed once with wash buffer comprising PBS with $0.05 \%$ Tween 20 and blocked with blocking buffer comprising PBS with $5 \%$ skim milk and $0.05 \%$ Tween 20 for $1 \mathrm{~h}$. After blocking, the membranes were incubated with target antibodies (against iNOS, STAT1, and $\beta$-tubulin) at $4{ }^{\circ} \mathrm{C}$ overnight. After incubation, the membranes were washed and incubated for $2 \mathrm{~h}$ at room temperature with HRP-conjugated secondary antibody diluted to 1:2000 in blocking buffer. The proteins bands were detected using a chemiluminescence detection system (GE Healthcare, Bucks, UK).

\subsection{Measurement of IL-6, MCP-1, TNF- $\alpha$ and IFN- $\beta$ Levels}

Cells were cultured in six-well plates at a density of $2 \times 10^{5}$ cells $/ \mathrm{mL}$ for $24 \mathrm{~h}$. The cells were pre-treated with various concentrations of lupinalbin $\mathrm{A}(5-100 \mu \mathrm{M})$ for $2 \mathrm{~h}$ and then stimulated with LPS $(1 \mu \mathrm{g} / \mathrm{mL})$ for $18 \mathrm{~h}$. IL-6, MCP-1, IL- $1 \beta$, TNF- $\alpha$, and IFN- $\beta$ levels were measured using an ELISA kit. The results are presented as mean \pm SDs of three replicates for one representative experiment.

\subsection{Quantitative Real-Time PCR Analysis}

Cells were cultured in six-well plates at a density of $2 \times 10^{5}$ cells $/ \mathrm{mL}$ for $24 \mathrm{~h}$. The cells were pre-treated with various concentrations of lupinalbin A (5-100 $\mu \mathrm{M})$ for $2 \mathrm{~h}$ and then stimulated with LPS $(1 \mu \mathrm{g} / \mathrm{mL})$ for $18 \mathrm{~h}$. Total RNA was isolated using the QIAGEN RNeasy kit (QIAGEN, Hilden, Germany). The PrimeScript II 1st Strand cDNA Synthesis Kit was used for reverse transcription according to the manufacturer's protocol. A Chromo4 real-time PCR detection system (Bio-rad, CA, USA) and SYBR were used for RT-PCR amplification for iNOS, IL-6, TNF- $\alpha$, MCP-1, and $\beta$-actin using the following conditions: 50 cycles of $94{ }^{\circ} \mathrm{C}$ for $20 \mathrm{~s}, 60^{\circ} \mathrm{C}$ for $20 \mathrm{~s}$, and $72{ }^{\circ} \mathrm{C}$ for $30 \mathrm{~s}$. Primers sequences are listed in Table 1.

Table 1. Primers used for the quantitative real-time PCR.

\begin{tabular}{cc}
\hline Gene & \multicolumn{1}{c}{ Sequence $\mathbf{( 5}^{\prime}$ to $\mathbf{3}^{\prime}$ ) } \\
\hline iNOS & $\begin{array}{c}\text { Forward: TCCTACACACCAAACTGTGTGC } \\
\text { Reverse: CTCCAATCTCTGCCTATCCGTCTC }\end{array}$ \\
\hline$I L-6$ & $\begin{array}{r}\text { Forward: GTTCTCTGGGAAATCGTGGAA } \\
\text { Reverse: GCAAGTCCATCATCGTTGTTC }\end{array}$ \\
\hline TNF- $\alpha$ & $\begin{array}{c}\text { Forward: GCCACCACGCTCTTCTGTCTAC } \\
\text { Reverse: GGGCTACAGGCTTGTCACTCG }\end{array}$ \\
\hline MCP-1 & $\begin{array}{c}\text { Forward: GCATCTGCCCTAAGGTCTTCA } \\
\text { Reverse: GTGGAAAAGGTAGTGGATGCATT }\end{array}$ \\
\hline -actin & $\begin{array}{l}\text { Forward: TGAGAGGGAAATCGTGCGTGAC } \\
\text { Reverse: GCTCGTTGCCAATAGTGATGACC }\end{array}$ \\
\hline
\end{tabular}

The expression of genes in comparison to the $\beta$-actin gene was evaluated by the comparative $C_{T}$ threshold method using Bio-Rad's software tool Genex-Gene Expression Macro (Chromo4, Bio-Rad, Hercules, CA, USA) [39]. The results are presented as mean \pm SDs of three replicates for one representative experiment. 


\subsection{Statistical Analysis}

All experimental data are presented as mean \pm standard deviations (SDs). Differences between data sets were assessed by one-way analysis of variance (ANOVA) followed by Tukey's multiple comparison test. A $p$ value of $<0.05$ was considered statistically significant.

Supplementary Materials: Supplementary materials are available online. Figure S1: ${ }^{1} \mathrm{H}-\mathrm{NMR}$ spectrum of lupinalbin A, Figure S2: ${ }^{13} \mathrm{C}-\mathrm{NMR}$ spectrum of lupinalbin A.

Acknowledgments: This work was supported by the R\&D program of the Korea Atomic Energy Research Institute and the National Research Foundation of Korea (NRF) grant funded by the Korea government (MSIP) (No. 2017M2A2A6A05018541).

Author Contributions: C.H.J. designed the experiments; H.-Y.K. and Y.K.S. performed the experiments; H.-Y.K. and C.H.J. analyzed the data; J.H.K. isolated and confirmed the lupinalbin A; H.-Y.K. provided the plant materials; H.-Y.K. and C.H.J. worte the paper; H.G.J. verified and improved the final results; All authors read and approved the final manuscript for submission.

Conflicts of Interest: The authors declare that there are no conflicts of interest.

\section{Abbreviations}

$\begin{array}{ll}\text { DMEM } & \text { Dulbecco's Modified Eagle's Medium } \\ \text { ELISA } & \text { Enzyme-linked immunosorbent assay } \\ \text { eNOS } & \text { Endothelial NOS } \\ \text { FBS } & \text { Fetal bovine serum } \\ \text { iNOS } & \text { Inducible NOS } \\ \text { MCP } & \text { Monocyte chemoattractant protein } \\ \text { IFN } & \text { Interferon } \\ \text { LPS } & \text { Lipopolysaccharide } \\ \text { NO } & \text { Nitric oxide } \\ \text { NOS } & \text { NO synthase } \\ \text { nNOS } & \text { Neuronal NOS } \\ \text { TNF } & \text { Tumor necrosis factor }\end{array}$

\section{References}

1. Medzhitov, R. Origin and physiological roles of inflammation. Nature 2008, 454, 428-435. [CrossRef] [PubMed]

2. Libby, P.; Ridker, P.M.; Maseri, A. Inflammation and atherosclerosis. Circulation 2002, 105, 1135-1143. [CrossRef] [PubMed]

3. Manzi, S.; Wasko, M.C. Inflammation-mediated rheumatic diseases and atherosclerosis. Ann. Rheum. Dis. 2000, 59, 321-325. [CrossRef] [PubMed]

4. Tak, P.P.; Firestein, G.S. NF-kB: A key role in inflammatory diseases. J. Clin. Investig. 2001, 107, 7-11. [CrossRef] [PubMed]

5. Marletta, M.A. Nitric oxide synthase structure and mechanism. J. Biol. Chem. 1993, 268, 12231-12234. [PubMed]

6. Rossol, M.; Heine, H.; Meusch, U.; Quandt, D.; Klein, C.; Sweet, M.J.; Hauschildt, S. LPS-induced cytokine production in human monocytes and macrophages. Crit. Rev. Immunol. 2011, 31, 379-446. [CrossRef] [PubMed]

7. Kawai, T.; Takeuchi, O.; Fujita, T.; Inoue, J.; Muhlradt, P.F.; Sato, S. Lipopolysaccharide stimulates the MyD88-independent pathway and results in activation of IFN-regulatory factor 3 and the expression of subset of lipopolysaccharide-inducible genes. J. Immunol. 2001, 167, 5887-5894. [CrossRef] [PubMed]

8. Piras, V.; Selvarajoo, K. Beyond MyD88 and TRIF pathways in Toll-like receptor signaling. Front. Immunol. 2014, 5, 1-3. [CrossRef] [PubMed] 
9. Fujihara, M.; Muroi, M.; Tanamoto, K.; Suzuki, T.; Azuma, H.; Ikeda, H. Molecular mechanisms of macrophage activation and deactivation by lipopolysaccharide: Roles of the receptor complex. Pharmacol. Ther. 2003, 100, 171-194. [CrossRef] [PubMed]

10. Lu, Y.C.; Yeh, W.C.; Ohashi, P.S. LPS/TLR4 signal transduction pathway. Cytokine 2008, 42, $145-151$. [CrossRef] [PubMed]

11. Gao, J.J.; Filla, M.B.; Fultz, M.J.; Vogel, S.N.; Russell, S.W.; Murphy, W.J. Autocrine/paracrine IFN- $\alpha \beta$ mediates the lipopolysaccharide-induced activation of transcription factor Stat $1 \alpha$ in mouse macrophages: Pivotal role of Stat $1 \alpha$ in induction of the inducible nitric oxide synthase gene. J. Immunol. 1998, 161, 4803-4810. [PubMed]

12. Nara, K.; Nihei, K.I.; Ogasawara, Y.; Koga, H.; Kato, Y. Novel isoflavone diglycoside in groundnut (Apios americana Medik). Food Chem. 2011, 124, 703-710. [CrossRef]

13. Wilson, P.W.; Gorny, J.R.; Blackmon, W.J.; Rwynolds, B.D. Fatty acids on the American groundnut (Apios americana). J. Food Sci. 1986, 51, 1387-1388. [CrossRef]

14. Wilson, P.W.; Pichardo, F.J.; Liuzzo, J.A.; Blackmon, W.J.; Rwynolds, B.D. Amino acids on the American groundnut (Apios americana). J. Food Sci. 1987, 52, 224-225. [CrossRef]

15. Iwai, K.; Kuramoto, S.; Matsue, H. Suppressing effect of Apios americana on blood pressure in SHR and its active peptide. J. Clin. Biochem. Nutr. 2008, 43, 315-318.

16. Cui, J.; Kim, Y.S.; Lee, E.B.; Kim, J.K.; Kang, T.H.; Jang, H.H. Immunostimulatory activity of apios tuber extract on RAW264.7 macrophage cells. J. Bacteriol. Virol. 2016, 46, 248-257. [CrossRef]

17. Iwai, K.; Matsue, H. Ingestion of Apios americana Medikus tuber suppresses blood pressure and improves plasma lipids in spontaneously hypertensive rats. Nutr. Res. 2007, 27, 218-224. [CrossRef]

18. Zhang, Y.; Zhou, C.; Tang, S.; Yu, X.; Kouzuma, Y.; Yonekura, M. Effect of AATI, a Bowman-Birk type inhibitor from Apios americana, on proliferation of cancer cell lines. Food Chem. 2011, 128, 909-915. [CrossRef]

19. Masilamani, M.; Wei, J.; Sampson, H.A. Regulation of the immune response by soybean isoflavones. Immunol. Res. 2012, 54, 95-110. [CrossRef] [PubMed]

20. Hajto, T.; Hostanska, K.; Frei, K.; Rordorf, C.; Gabius, H.J. Increased secretion of tumor necrosis factor $\alpha$, interleukin 1, and interleukin 6 by human mononuclear cells exposed to $\beta$-galactoside-specific lectin from clinically applied mistletoe extract. Cancer Res. 1990, 50, 3322-3326. [PubMed]

21. Kenmochi, E.; Kabir, S.R.; Ogawa, T.; Naude, R.; Tateno, H.; Hirabayashi, J. Isolation and biochemical characterization of Apios tuber lectin. Molecules 2015, 24, 358-363. [CrossRef] [PubMed]

22. Khwaja, T.A.; Dias, C.B.; Pentecost, S. Recent studies on the anticancer activities of mistletoe (Viscum album) and its alkaloids. Oncology 1986, 43 (Suppl. 1), 42-50. [CrossRef] [PubMed]

23. Kim, J.H.; Kim, H.Y.; Kang, S.Y.; Kim, Y.H.; Jin, C.H. Soluble epoxide hydrolase inhibitory activity of components isolated from Apios americana Medik. Molecules 2017, 22, 1432. [CrossRef] [PubMed]

24. Song, S.H.; Lee, S.Y.; Cui, J.; Jang, H.H.; Kang, T.H.; Kim, J.K.; Kim, I.K.; Lee, D.K.; Choi, S.G.; Yoon, I.S.; et al. Apios americana Medik extract alleviates lung inflammation in influenza virus H1N1-and endotoxin-induced acute lung injury. J. Microbiol. Biotechnol. 2015, 25, 2146-2152.

25. Takashima, M.; Nara, K.; Niki, E.; Yoshida, Y.; Hagihara, Y.; Stowe, M.; Horie, M. Evaluation of biological activities of a groundnut (Apios americana Medik) extract containing a novel isoflavone. Food Chem. 2013, 138, 298-305. [CrossRef] [PubMed]

26. Ateba, S.B.; Njamen, D.; Medjakovic, S.; Zehl, M.; Kaehlig, H.; Jungbauer, A.; Krenn, L. Lupinalbin A as the most potent estrogen receptor $\alpha$ - and aryl hydrocarbon receptor agonist in Eriosema laurentii de Wild (Leguminosae). BMC Complement. Altern. Med. 2014, 14, 294. [CrossRef] [PubMed]

27. Bai, Y.; Xu, Y.; Chang, J.; Wang, X.; Zhao, Y.; Yu, Z. Bioactives from stems and leaves of mung beans (Vigna radiata L.). J. Funct. Foods 2016, 25, 314-322. [CrossRef]

28. Gagnon, H.; Tahara, S.; Bleichert, E.; Ibrahim, R.K. Separation of aglucones, glucosides and prenylated isoflavones by high-performance liquid chromatography. J. Chromatogr. 1992, 606, 255-259. [CrossRef]

29. Kang, W.J.; Li, D.H.; Han, T.; Sun, L.; Fu, Y.B.; Sai, C.M.; Li, Z.L.; Hua, H.M. New chalcone and pterocarpoid derivatives from the roots of Flemingia philippinensis with antiproliferative activity and apoptosis-inducing property. Fitoterapia 2016, 112, 222-228. [CrossRef] [PubMed]

30. Lin, C.F.; Liu, Y.W.; Kuo, Y.H.; Shen, C.C.; Chiou, W.F.; Chen, C.C. Flavonoids and bis-coumarin from the tubers of Apios taiwanianus. Phytochem. Lett. 2016, 15, 164-167. [CrossRef] 
31. Sun, F.; Li, Q.; Xu, J. Chemical composition of roots Flemingia philippinensis and their inhibitory kinetics on aromatase. Chem. Biodivers. 2017, 14, e1600193. [CrossRef] [PubMed]

32. Chakrabarti, S.; Lekontseva, O.; Davidge, S.T. Estrogen is a modulator of vascular inflammation. IUBMB Life 2008, 60, 376-382. [CrossRef] [PubMed]

33. Wei, J.; Chen, J.R.; Pais, E.M.A.; Wang, T.Y.; Miao, L.; Li, L.; Li, L.Y.; Qiu, F.; Hu, L.M.; Gao, X.M.; et al. Oxyresveratrol is a phytoestrogen exerting anti-inflammatory effects through NF- $\kappa \mathrm{B}$ and estrogen receptor signaling. Inflammation 2017, 40, 1285-1296. [CrossRef] [PubMed]

34. Alderton, W.K.; Cooper, C.E.; Knowles, R.G. Nitric oxide synthases: Structure, function and inhibition. Biochem. J. 2001, 357, 593-615. [CrossRef] [PubMed]

35. Bogdan, C. Nitric oxide and the immune response. Nat. Immunol. 2001, 2, 907-916. [CrossRef] [PubMed]

36. Kopf, M.; Bachmann, M.F.; Marsland, B.J. Averting inflammation by targeting the cytokine environment. Nat. Rev. Drug Discov. 2010, 9, 703-718. [CrossRef] [PubMed]

37. Song, S.M.; Ham, Y.M.; Ko, Y.J.; Ko, E.Y.; Oh, D.J.; Kim, C.S.; Kim, D.K.; Kim, K.N.; Yoon, W.J. Anti-inflammatory activites of the products of supercritical fluid extraction from Litsea japonica fruit in RAW264.7 cells. J. Funct. Foods 2016, 22, 44-51. [CrossRef]

38. Jin, C.H.; Lee, H.J.; Park, Y.D.; Choi, D.S.; Kim, D.S.; Kang, S.Y.; Seo, K.I.; Jeong, I.Y. Isoegomaketone inhibits lipopolysaccharide-induced nitric oxide production in RAW264.7 macrophages through the heme oxygenase- 1 induction and inhibition of the interferon- $\beta$-STAT-1 pathway. J. Agric. Food Chem. 2010, 58, 860-867. [CrossRef] [PubMed]

39. Canesi, L.; Borghi, C.; Ciacci, C.; Fabbri, R.; Vergani, L.; Gallo, G. Bisphenol-A alters gene expression and functional parameters in molluscan hepatopancreas. Mol. Cell. Endocrinol. 2007, 276, 36-44. [CrossRef] [PubMed]

Sample Availability: Samples of the compounds are not available from the authors.

(C) 2018 by the authors. Licensee MDPI, Basel, Switzerland. This article is an open access article distributed under the terms and conditions of the Creative Commons Attribution (CC BY) license (http:/ / creativecommons.org/licenses/by/4.0/). 